No. 3(60), 2019, pp. 303-322

https://doi.org/10.12797/Politeja.16.2019.60.20

Jovan BAZIĆ

University of Pristina-Kosovska Mitrovica

jovan.bazic@pr.ac.rs

\title{
RELATIONS OF SERBIA
}

AND EUROPEAN UNION:

SOCIO-HISTORICAL DETERMINANTS

AND THE CONTEMPORARY

POLITICAL ISSUES ${ }^{1}$

ABSTRACT This paper deals with the relations between the Republic of Serbia and the European Union, with special attention to the key issues in the process of its accession to the EU, as well as the political moods of the Serbian citizens towards that membership. There are many problems and misunderstandings in the process of Serbia's accession to the European Union which are expressed through conflicts of different interests, the EU's asymmetrical and ultimatumbased relationship with Serbia, a different perception and assessment of reality in Serbia, the value system and other cultural factors. These problems are manifested through many issues, and essentially, they stem from the consequences of the break-up of Yugoslavia and the political conditions for Serbia's admission to EU membership, such as: the support of the secessionist processes in the Federal Republic of Yugoslavia, first in case of secession of Montenegro from the FR Yugoslavia and then of Kosovo and Metohija from Serbia, as well as in the issues of Serbia's cooperation with the Hague Tribunal. The core standards for EU membership from Copenhagen and Madrid remain in the shadow of these problems. This is one of the reasons why in Serbia the skepticism towards its membership in the European Union has been on the rise. Other contributing reasons for skepticism include the current processes within the Union, such as

This paper is the result of working on a project at the Institute for Political Studies in Belgrade: Democratic and National Capacities of Political Institutions in Serbia in the Process of International Integrations, financed by the Ministry of Science and Technological Development of the Republic of Serbia (Project Number: 179009). 
economic, monetary and institutional crisis, Brexit; the strengthening of conservatism and separatism, as well as the increasingly noticeable initiatives for the reorganization of the Union. That is why Serbia's path to EU membership has become more complicated and why it seems more and more like a road without a final destination.

Key words: Serbia, European Union, EU integration

\section{SERBIA AND EUROPEAN INTEGRATION FROM A YUGOSLAV CONTEXT}

The Serbian path towards European integration started with the struggle of Serbian politicians and intellectuals for political ideas on European unity within the Yugoslav framework and then continued through the participation of socialist Yugoslavia in the processes of European integration and its decline from the political map of Europe, as well as in post-Yugoslav political circumstances. Ideas and concepts about European unity and the European community of states that would prevent a new world war emerged in Europe right after the First World War. To this end, various diplomatic activities were launched, especially in France and Germany. All this brought forth the attention of numerous Serbian politicians and intellectuals, who supported the European ideas and contributed to their realization. Serbian diplomat Momčilo Ninčić took part in the Second Pan-European Congress in Berlin (1930) as a Yugoslav representative and supported the European idea of Aristide Briand and Gustav Stresemann, and, at this Congress, he advocated for "French-German rapprochement." The political thought of Dimitrije Mitrinović, a Serbian avant-garde critic and writer, was also along those lines, highlighting the ideas of "cultural synthesis of Europe" and the creation of a "European federation as the first step towards a world federation" (1931). In order to develop and popularize the ideas of European integration, he launched the New Europe (Nova Evropa) magazine $(1934)^{2}$. In the interwar period, European ideas were also expressed by Serbian politicians who emphasized the idea of the Balkan federation and participated in the work of the Balkan conferences. Among them, the most prominent were the activities of Dr. Živko Topalović, a Serbian lawyer and politician, who was also active in the movements for the unification of Europe. He continued to advocate for the unification of Europe even after the World War II had ended. Topalović, together with Milan Gavrilović and Juraj Krnjević, participated in the Hague Congress (1948), at which the unification of Europe was proclaimed and the creation of the Council of Europe was announced ${ }^{3}$. Topalović was also a participant at the European Federalist Movement gathering in Strasbourg (1948) and later founded the Association of

D. Lopandić, Evropska integracija izmedu nacije i globalizacije, Beograd 2017, pp. 9-17.

Živko Topalović, Milan Gavrilović (both Serbian) and Juraj Krnjević (Croatian) constituted the Yugoslav delegation-in-exile at the Hague Congress. This delegation, as well as other delegations of the representatives of the civilian parties of the eastern European countries in exile, had the status of 
Serbian Federalists (1956), which included many Serbian exiled politicians who were in conflict with the communist regime in Yugoslavia.

During the postwar reconstruction, especially after the Information Bureau (Informbiro) Resolution (1948) and the blockade by the East-European countries, Yugoslavia started increasingly turning towards the West and gradually taking part in the European integration processes. Yugoslavia had had well-developed relations with the Council of Europe since its formation $(1949)^{4}$ and had, with special attention, followed the emergence and the development of the European Economic Community (EEC), the European Free Trade Association (EFTA), The Council for Mutual Economic Assistance (SEV) and the Organization for Economic Cooperation and Development $(\mathrm{OECD})^{5}$. At the same time, Yugoslavia joined these associations and developed appropriate cooperation with them. Yugoslavia was also formally and indirectly involved in the Western military-political structures through the treaties on friendship and cooperation with Greece and Turkey (1953-1954)6. Then came the establishment of bilateral trade agreements with the Western European countries, especially in the period from 1958 to 1968. In the 1960s, alongside the development of the NonAligned Movement, Yugoslavia was increasingly linked to the EEC, which was particularly noticeable after 1967, when they had institutionalized and contractual relations. At the end of 1967, the Declaration on relations between SFR Yugoslavia and EEC was signed, which provided the framework for the economic cooperation, and during the following year, a permanent Yugoslav mission in Brussels was established. This simultaneously started the negotiation process for the conclusion of a special threeyear trade agreement, which happened in $1971^{7}$. After that, the Declaration on the Regulatory Relationship of SFR Yugoslavia with the EEC was signed (1976). After lengthy preparations, a comprehensive agreement on economic and trade cooperation was signed (1980). It had an unlimited duration, unlike the previous three-year agreements. Based on this declaration and other measures subsequently introduced, exports

observers. See more: R. Milikić, Zaboravljena evropska epizoda. Jugoslavija i Savet Evrope, 1949-1958, Beograd 2014, p. 83.

4 R. Petković, Savet Evrope 1949-1996, Beograd 1996, pp. 299-300.

5 R. Kovačević, Ekonomski odnosi Srbije sa inostranstvom, Beograd 2017, pp. 159-186, 225-236.

6 In 1953 (on February 28th), a treaty of friendship and cooperation between Yugoslavia, Greece, and Turkey was signed, regulating a co-operation between these countries in the field of security, economy, technology, and culture. By the end of that same year, this agreement was supplemented by provisions establishing a permanent secretariat of the Foreign Affairs Ministers' Conference. Then, on February 28th, 1954 , based on this treaty, a secret convention on political co-operation and mutual military assistance in case of an outside attack was adopted. See M. Stojković, Balkanski ugovorni odnosi 1876-1996. Dvostrani i višestrani međunarodni ugovori i drugi diplomatski akti o državnim granicama, političkoj i vojnoj saradnji, verskim i etničkim manjinama, vol. 3: 1946-1996, Beograd 1999, pp. 235-254.

Based on this agreement, in 1971 Yugoslavia was included in the European program for scientific and technical cooperation, and by the middle of the same year, a general scheme of preferences was adopted in the economic cooperation between the SFRY and the EEC. It meant the co-operation in finance, science, and technology, commodity exchange, agriculture, and industry. At the same time, customs duties on many industrial products were abolished. 
to the European Community countries were liberalized, and many benefits were obtained for the export of agricultural products. Therefore, in the total foreign trade, in the course of 1987, Yugoslavia realized $34.8 \%$ of exports to and $40 \%$ of imports from the EEC countries. ${ }^{8}$. On the other hand, Yugoslavia soon found itself among the ten most important economic partners of the EEC. At the same time, Yugoslavia was also receiving significant financial and technical assistance from the European Community and its member countries.

Since 1980, the Permanent Delegation of the European Economic Community had been working in Belgrade, which represented a significant institutional support for the cooperation. During the 1980s, several business forums were held between the EEC member states and SFRY, bringing together businessmen, bankers, and other business people, thus extending the cooperation to infrastructure projects. Between 1975 and 1990, there was a Council for Cooperation between the EEC and SFRY at the ministerial level, which met nine times? ${ }^{9}$. Also, during the same period, several meetings of the representatives of the SFRY Assembly and the European Parliament in Strasbourg were held ${ }^{10}$. At the beginning of 1990, the SFRY Assembly adopted the Declaration on European Integration, which meant a fundamental shift from the policy of non-alignment towards the European integration policy ${ }^{11}$. Also, at that time, Yugoslavia signed the PHARE program, which implied financial support in the coming transition, social and economic reforms. It seemed that Yugoslavia would soon become a full member of the European Economic Community. However, due to the culmination of the crisis and the beginning of the war in Yugoslavia, all the agreements on cooperation between the SFRY and the European Community were soon suspended.

\section{SERBIA AND THE EEC/EU RELATIONS (1991-2018)}

This period of relations between Serbia and the European Community/Union can be viewed through two qualitatively different stages. The first, the beginning of which coincides with the beginning of the war in Yugoslavia (1991), lasted until the overthrow of the Slobodan Milošević's regime (October 5th, 2000). At the same time, with the

8 G. Nikolić, Pokazatelji spoljnotrgovinske razmene Srbije sa Evropskom unijom i svetom, Beograd 2010, p. 14.

$9 \quad$ A. Živković, "Kratka historija evropskih integracija”, in M. Kostanić (ed.), Dva desetljeća poslije kraja socijalizma. Zbornik radova, Zagreb 2014, pp. 26-54.

10 L. Adamović (ed.), Jugoslavija i Evropska ekonomska zajednica, Beograd 1988, pp. 243-246.

11 Deklaracija Skupštine Jugoslavije o daljnjem uključivanju SFR Jugoslavije u integracijske procese u Evropi, Službeni list SFRJ, br. 50, Beograd, 26. januara 1990 (The Declaration by the Assembly of Yugoslavia on the further inclusion of SFR Yugoslavia in the integration processes in Europe, The Official Gazette of SFRY, no. 50, Belgrade, 26 January 1990), p. 290. This Declaration explicitly indicated that the SFRY would seek to enter the European Community and the European Free Trade Association. Later, Deklaracija Skupštine SFRJ o evropskim integracijama, Službeni list SFRJ, br. 30, Beograd, 26. aprila 1991 (the Declaration of the SFRY Assembly on European Integration followed, The Official Gazette of SFRJ, no. 30, Belgrade, 26 April 1991), p. 542. 
beginning of the second stage also begins the establishment of a new, neoliberal and pro-European regime led by Vojislav Koštunica.

In the first stage (1991-2000), the cooperation of the European Community, and then of the European Union (EU) with the FR Yugoslavia (Serbia and Montenegro), was minimized and it moved at an unstable course with great misunderstandings and conflicts. In addition, the European Community/Union was neither at the center of the attention of relevant political figures in Serbia ${ }^{12}$ in the 1990s nor in the campaign for the crucial 2000 elections, so "it did not represent a significant topic in Serbia's political life"13. On the other hand, in this period, the EEC/EU had a major impact on the outcomes of the Yugoslav crisis and the consolidation of new states in the postYugoslavian territories, by immediately recognizing some of them (Slovenia, Croatia, Bosnia and Herzegovina and Macedonia), and adopting a reserved attitude towards FR Yugoslavia and joining the UN sanctions. During 1994, some sanctions on FR Yugoslavia were partially lifted (air and maritime transport), and their end came one year after the signing of the Dayton Accords (1996), which ended the war in Bosnia and Herzegovina. A more significant improvement of the relations took place early next year when preferential treatment for the goods from Serbia and Montenegro was introduced. However, this was short-lived as even heavier sanctions were introduced at the beginning of 1998 because of the armed conflicts in Kosovo and Metohija, followed by the NATO bombing of FR of Yugoslavia (March 24th, 1999).

In the second stage (2000-2018), after the new political elites came to power, the process of changing the political regime in Serbia and the radical economic reforms began. What also began was the process of bringing Serbia closer to the European Union, which was considered to be the basic prerequisite for "the general stabilization and consolidation of the country" ${ }^{14}$. In the last quarter of 2000, there was very intensive cooperation between the FRY and the European Union. As early as October 9th this year, the EU Council of Ministers lifted most of the sanctions against the FRY, and the process of renewing political dialogue, normalization of relations and cooperation between the FRY and the EU began with the participation of the new President of the Federal Republic of Yugoslavia (Vojislav Koštunica) at the EU Summit in Biarritz (October 2000). Also, at that time (October 31st), FR Yugoslavia was admitted to the United Nations.

In this context, it is a very important fact that when the Lisbon Declaration on EU Strategic Goals until 2010 was adopted, the European Council meeting in Lisbon (March 23-24th, 2000) estimated that the European Union's economy was increasingly falling behind in the global market, that there was an even more marked unemployment rate and aging of the population in the EU member states, which required greater social benefits, "and that the EU is facing the problem of accepting new members,

\footnotetext{
12 S. Biserko, Yugoslavia's Implosion. The Fatal Attraction of Serbian Nationalism, Oslo 2012, pp. 33-124.

13 V. Koštunica, Politička neutralnost ili Evropska unija, Beograd 2013, p. 13.

14 S. Samardžić, Evropska unija. Sistem u krizi. Sa studijom slučaja o odnosima Srbije i EU, Novi Sad 2016, p. 331 .
} 
predominantly poor countries, which is a major economic and social challenge"15. This assessment largely influenced the European Union's relationship with the Western Balkan states, whose accession to the EU membership was significantly slowed down by additional procedures. This was immediately apparent at the Zagreb Summit of the EU and the Western Balkans (November 24th, 2000), when the Balkan states were told they were potential candidates for the EU membership. In November of that same year, FR Yugoslavia was included into the Stabilization and Association Process, which was a more developed, innovative form of the regional approach for the Western Balkans. This process includes a series of unilateral and bilateral measures towards the Balkan countries, provided that it meets certain political and economic conditions. On December 1st of that year, the FRY received an autonomous preferential treatment from the EU, which put most of its domestic export on a tax-free regime. Since then, there has been an increase in trade exchange with the EU member states. Soon the FRY made a significant breakthrough in fulfilling the Copenhagen Accession criteria related to the building a democratic society, a market economy, the rule of law and the respect for human rights. However, in spite of this, the process of accession of the FRY to EU has been very slow because of the new and increasingly difficult political conditions for EU membership, but primarily because of the "consequences of unresolved political and institutional problems inherited from the previous decade" ${ }^{16}$. During 2003 there was already a halt in the development of cooperation with the EU because of the assassination of the Prime Minister Zoran Đinđić. Subsequently, there were several changes to the conditions for Serbia and negotiations were suspended for various reasons, but mostly political, including the most prominent ones: the relations of Serbia with Montenegro and cooperation with the Hague Tribunal. The more decisive steps to overcome these problems were made in October 2004 with the double-track model as well as by intensifying the cooperation with the Hague Tribunal in early 2005. Serbia gained the exemptions for exporting sugar and textiles to the EU. At the beginning of April of the same year, Serbia received a positive feasibility study, pointing to a path towards full European integration which was a significant factor in the growth of the confidence of potential investors. In June 2005, a draft of the National Strategy for Serbia's EU Accession was presented. In it, the guidelines, priorities, and instructions for the state bodies were given, and the goals of Serbia's integration into the EU were placed in a broader framework of Serbia's development. In October that year, the EU approved the beginning of negotiations on the Stabilization and Association Agreement (SAA), but they were broken off (they lasted from May 2006 to September 2007) due to the Hague Tribunal Chief Prosecutor's assessment that Serbia had not cooperated enough with this court.

During the negotiation process, Serbia faced an unexpected obstacle. It was about the readiness of the Western member states of the Contact Group to recognize Kosovo

15 J. Bazić, M. Knežević, "Knowledge in EU Development Strategies", Knowledge. International Journal, vol. 15, no. 1 (2016), pp. 83-88.

16

D. Lopandić, Evropska integracija..., p. 191. 
and Metohija as an independent state, breaking the general international rules and UN Security Council Resolution 1244. That is why the accession negotiations were held at the same time as Kosovo status negotiations. These latter were interrupted without results (December 2007), and soon after, Kosovo's independence was announced (17.02.2008). After that, a concession was made by the EU for Serbia, so a signing of the Stabilization and Association Agreement did take place (29.04.2008), ${ }^{17}$ but the accession process was taking place under the new conditions for Serbia - "normalization of relations with Kosovo". That is why the Stabilization and Association Agreement was soon frozen again, which lasted until December 7 th, 2009, and its ratification was conditioned by "full cooperation" with the Hague Tribunal. This condition was dominant until 2012 when all the people Hague had sought were captured and extradited.

Meanwhile (September 2009), the EU approved visa liberalization for Serbian citizens, but with two rather absurd conditions. The first one was that the Agreement on visa liberalization was linked to the Readmission Agreement, bearing in mind that most of those seeking visas to the EU countries, especially for Germany, were the Kosovo Albanians with Serbian passports. The second was that Serbia had to agree to the discriminatory application of the visa agreement, because the new biometric passports, upon the explicit request of the Union, could not be issued to Serbs living in Kosovo and Metohija. In the process of constant and atypical conditionality, Serbia was in a position to submit an official application for the membership to the European Union only on December 22nd, 2009. In this stage of the development of relations between Serbia and the European Union, with the liberalization of political and economic relations, there was also an increase in foreign trade. By 2008, exports and imports grew at an average rate of $19 \%$ or $19.8 \%$ in euros annually ${ }^{18}$. However, the economic and monetary crisis, which reached its peak in Europe in 2008, did not miss Serbia, which made the bad socio-economic situation even worse and created new problems.

For 2011, the European Commission ordered Serbia to carry out tasks related to: the mandates of the members of parliament, improvement of Roma integration, finalization of the judicial reform, completion of cooperation with the Hague Tribunal, improvement in the regional cooperation, undisturbed functioning of regulatory bodies, new law on political party financing, the solution to the problem of the increased number of asylum seekers, the adoption of restitution laws and the continuation of structural economic reforms "which should enable a sustainable development of the economy"19.

Following the many complications and concessions that Serbia still had to make, the European Council adopted the conclusion on granting Serbia the status of candidate

17 Sporazum o stabilizaciji i pridruživanju između Evropskih zajednica i njihovih država članica, sa jedne strane, i Republike Srbije, sa druge strane, koji je potpisan 29. aprila 2008. godine u Luksemburgu, Službeni glasnik Republike Srbije, br. 83, septembar 2008 (The Stabilization and Association Agreement between the European Communities and their member states, on the one side, and the Republic of Serbia on the other, was signed on April 29th, 2008 in Luxembourg, Official Gazette of the Republic of Serbia, no. 83, September 2008).

18 G. Nikolić, Pokazatelji spoljnotrgovinske razmene..., p. 14.

19 S. Grk, “Srbija i Evropska unija - krize posle krize”, Srpska politička misao, no. 2 (2011), p. 126. 
for accession to the European Union on March 1st, 2012. Soon after the European Parliament's resolution on Serbia's progress for $2012,{ }^{20}$ the opening of accession negotiations followed, as well as the conclusion of the Stabilization and Association Agreement (28.06.2013). The first intergovernmental conference on Serbia's accession to the European Union was held on January 24th, 2014 in Brussels. From December 2015 until the end of December 2017, ten out of thirty-five negotiating chapters were open ${ }^{21}$.

Also, Serbia signed seven agreements with the $\mathrm{EU}^{22}$. At the same time, in this period (2000-2018), there was a major enlargement of the European Union by the 13 new states, and Serbia remained to wander through the maze of written and unwritten conditions and unforgiving deadlines.

\section{KEY PROBLEMS IN SERBIA - EU RELATIONS}

Since the end of 2000, when Serbia renewed its European path in order to become a member of the European Union, it has continuously had to face great obstacles, unforeseen and asymmetric conditions, political problems and conflicts. In Serbia's case, the criteria for accession to the European Union, as laid down in Copenhagen (1993) ${ }^{23}$ and Madrid (1995), such as political and economic stability, acceptance of the Union's legal legacy and its implementation in national legislations, all remained in the shadow of many political conditions and ultimatums. However, the supplementary criteria for the Western Balkan states, through which the Stabilization and Association Process was introduced, came to the forefront, and they became unpredictable. In addition, Serbia was given many conditions that were not set to other Balkan countries which were candidates for the EU membership ${ }^{24}$. This was particularly evident through the ulti-

20 See European Parliament resolution of 18 April 2013 on the 2012 Progress Report on Serbia.

21 According to the order of their opening, these are the chapters on: financial supervision (32); normalization of relations between Belgrade and Priština (35); judicial system and fundamental rights (23); justice, freedom and security (24); entrepreneurship and industrial policy (20); education and culture (26); the right of intellectual property (7); customs union (29); the right of companies (6); and on economic relations with foreign countries (30). See: Ministarstvo za evropske integracije Republike Srbije, Istorijat odnosa Srbije i EU, Beograd 2018, at <http://www.mei.gov.rs/src/srbija-i-eu/istorijat-odnosa-srbije-i-eu/>.

22 The Agreement on Establishment of the Transport Community, the Stabilization and Association Agreement, the Agreements on Trade in Textile and Textile Products, the Energy Community for South East Europe, the Open Skies Agreement, the Free Trade Agreement in the Balkans (CEFTA) and the Visa Facilitation and Readmission Agreement. See: Ministarstvo za evropske integracije Republike Srbije, Sporazumi sa EU, Beograd 2018, at <http://www.mei.gov.rs/src/dokumenta/sporazumi-sa-eu/>.

23 See more exemplum: E. Bujwid-Kurek, „Republika Serbii w kontekście kryteriów kopenhaskich - studium politologiczno-prawne", Horyzonty Polityki, vol. 4, no. 8 (2013), pp. 125-147. See also eadem, "Preparations of Western Balkan Countries for Integration with the European Union. Case of the Republic of Serbia”, in K. Bieniek (ed.), Republika Turcji. Polityka zagraniczna i wewnętrzna, Kraków 2016, pp. 49-50.

24 See more exemplum: eadem, “'Nieunijne’ państwa pojugosłowiańskie w obliczu integrującej się Europy - uwag kilka”, Studia Politologiczne, vol. 47 (2018), pp. 180-181. 
matum-based nature of the Union's attitudes in the process of separating Montenegro from the FR Yugoslavia and Kosovo and Metohija from Serbia, as well as on issues of Serbia's cooperation with the Hague Tribunal.

Although FR Yugoslavia was recognized as an international legal personality, the European Union did not consider FR Yugoslavia a unified political community, and as a result of that, it supported the separatist behavior of Montenegro. In December 2004, at the start of negotiations on the Stabilization and Association Agreement (SAA), the EU imposed a "twin track" approach on the basis of which Serbia and Montenegro were to negotiate the trade section of the SAA separately and the political part of this agreement as the State Union. Thus, in the EU, Serbia and Montenegro were actually treated separately, as two separate and independent entities, which later became even more noticeable. Then, non-governmental actors whose interests were dysfunctional in relation to the interests of the State Union of Serbia and Montenegro got more and more involved not only in the SAA negotiation process but also in the process of joining the Union as a whole ${ }^{25}$. In addition, the acceptance of the twin track was one of the key conditions for publishing a positive feasibility study in the spring of 2005.

The second condition was the acceptance of the Agreement on the Amendment of the Constitutional Charter, according to which it was necessary to hold the elections for the state union parliament first and only after that the referendum on the independence of Montenegro. Through its envoy, the Austrian diplomat Stefan Lehne, who was, at the time, an assistant to the High Representative of the European Union for Foreign Affairs, the EU extorted that the referendum on Montenegro's independence is held first and that the state union parliamentary elections are held only after the referendum. The following year (2006), a referendum was conducted: the turnout was $55 \%$ of Montenegrin citizens. Numerous referendum irregularities were tolerated and it was decided that Montenegro should be separated from the State Union of Serbia and Montenegro ${ }^{26}$. At the same time, while the EU decisively influenced the breakup of the State Union of Serbia and Montenegro, which was contrary to the Dayton Agreement, it conducted the centralization policy of Bosnia and Herzegovina, i.e. implemented its integration by the abolition of Republika Srpska, which occurred during the autumn of 2009 when the EU and the US were synchronized in their attempt to impose the constitutional changes that would change $\mathrm{BiH}$ 's form of government. The main reason for this was, as it was argued, "that $\mathrm{BiH}$ is a non-functioning state and that it needs to be centralized in order for it to better and more efficiently meet the conditions

25 This attitude of the Union can be understood through the neofunctionalist view of the role of the states in the integration process where it is indicated that the states are not the dominant actors in the international system, but that different actors are involved in the political process, which are not limited to the domestic political framework. See: B. Rosamond, Theories of European Integration, New York 2000.

26 The European Union stopped 260,000 Montenegrin citizens residing in Serbia from voting in the referendum. Documented irregularities, manipulations and theft on this referendum, as well as of the cooperation of the EU and the authorities in Podgorica, was collected and made into a special document of 1290 pages. See: J.B. Markuš, Bijela knjiga. Referendum u Crnoj Gori 2006. Zbornik dokumenata, Podgorica 2007. 
on its way towards the EU" ${ }^{27}$. This is seen as a rather unreasonable and unprincipled EU policy towards the countries of the Western Balkans for their accession to the EU.

In the case of Kosovo and Metohija, its separation from Serbia happened after the NATO bombing of FR Yugoslavia. Since the beginning of this aggression, Kosovo had received all the help of the western countries to form a complete state. The European Union had, again, great influence on this occasion, but everything it did was contrary to what it had previously done to tackle a similar problem - Cyprus's accession to the $\mathrm{EU}^{28}$. And in this case, the unprincipled policy of the EU and its asymmetrical attitude to Serbia were very noticeable. Initially, the EU's policy towards Kosovo expressed in the thesis "first standards then status", was to first achieve certain standards in a number of areas, such as building institutions, the return of displaced persons and reconstruction of their homes; and then approach the consideration of the status. But this did not last long. Already during 2004, there was a change of rhetoric and there was pressure to begin to resolve the status of Kosovo. Kosovo status negotiations began in Vienna (February 2006) and were mediated by Martti Ahtisaari, the former Finnish president. They lasted until November next year and officially ended without success. All Serbian proposals were rejected. From these negotiations, it was quite clear that they were looking only for a model of Kosovo's independence and minority protection for the Serbs living there. Serbia's participation in these negotiations was only one of a number of conditions for the continuation of European integration, especially for the signing of the Stabilization and Association Agreement. Serbia, as well as the UN Security Council, did not accept the proposal for the settlement of the Kosovo status, known as the "Ahtisaari plan"29. Following this failure, as well as the failure of the negotiating process of the US, EU and Russia, the United States and the European Union began the preparations for Kosovo's unilateral declaration of independence. The Council of Ministers of the EU, a few weeks before Kosovo's independence was declared (February 4th, 2008), adopted a joint action on the EU Mission, known as the EULEX mission ${ }^{30}$. With this mission, after Kosovo's declaration of independence, the European Union assumed police control, administration, and operational activities in Kosovo and Metohija, simultaneously suppressing the United Nations Mission (UNMIK). Later, it became increasingly apparent that the role of EULEX was to provide logistic support for building state institutions in Kosovo, and that the NATO provided

\section{S. Samardžić, Evropska unija..., p. 318.}

28 From the Serbian perspective, Kosovo and Metohija could have been treated as the EU did in the case of Cyprus. During the process of joining the European Union, the territory of the northern part of Cyprus was treated as a part of the sovereign and whole state, despite the fact that the Turks from the north of Cyprus did not want to return under the sovereign rule and jurisdiction in Nicosia. Also, there were neither asymmetric conditions and standards, nor was there insistence that the problem should be solved in order to accelerate the integration. After many failed peace initiatives, the EU only registered the fact that the conflict cannot be solved and the factual status of the division was accepted so that Cyprus as a whole was admitted to the European Union.

29 Comprehensive Proposal for the Kosovo Status Settlement (CSP), 2 February 2007.

30 Council Joint Action 2008/124/CFSP of 4 February 2008 on the European Union Rule of Law Mission in Kosovo, EULEX Kosovo, Official Journal of the European Union, L 42, 16 February 2008. 
the military support to proclaim Kosovo's independence. On February 17th, 2008, the Kosovo Assembly declared independence, and on the next day, the ministers of the EU member states issued conclusions indicating that they are committed to the principle of territorial integrity of all countries except Serbia, where Kosovo is designated as a sui generis, a "unique case" 31 . The purpose of using this phrase is to "avoid accountability because of its own participation in the violation of international law" ${ }^{\prime 2}$. Independence of Kosovo was immediately recognized or supported 22 of the 27 member states of the European Union as well as its institutions. This recognition was obviously contrary to international law, but also to the criterion of the Thessaloniki Agenda of "respecting the principle of inviolability of borders, peaceful settlement of disputes and cooperation in the region" 33 .

The Union continued to pressure Serbia, insisting that it should be working on starting "good neighborly relations with Kosovo" and that it should align its policy towards Kosovo and Metohija with the Ahtisaari plan, i.e. in fact to recognize Kosovo's independence.

These pressures from the EU to integrate Serbs into the state system of the "Independent Kosovo" was partially accepted by the Tadić administration, but it refused to do it for the four municipalities in the north. At the end of 2010, with the EU mediation, direct talks between Serbian authorities and representatives of Kosovo Albanians began. After the change in the Serbian government in the presidential elections in 2012, marked by the election of Tomislav Nikolić as the President of Serbia, the Agreement on Integrated Border Management was soon accepted, thus establishing the real borders between Serbia and its territories in the south - Kosovo and Metohija. Shortly after that, in April 2013, the first agreement on the principles of normalization of relations between Belgrade and Pristina was adopted ${ }^{34}$.

With it, Serbia abandoned the governing functions in four municipalities in the north of Kosovo and Metohija, accepted Kosovo legislation in all matters of the

31 "The Council reiterates its commitment to the EU principles of the UN Charter and the Helsinki Final Act, among other things, the principles of sovereignty and territorial integrity in all resolutions of the Security Council. It underlines its belief that, having the 1990s conflict in mind and the extended period of international administration under the Resolution 1244, Kosovo represents a unique case (sui generis) which does not call into question these principles and resolutions." See Council Conclusions on Western Balkans, PRESS, 18 February 2008. That Kosovo is not really sui generis, but a case of the illegal secession was soon shown by similar events in Georgia when its provinces Abkhazia and South Ossetia seceded, referring to "the Kosovo case". Their secession was not supported by the Union which expressed its "full commitment to the principle of sovereignty, independence and territorial integrity of Georgia in internationally recognized borders" (Council Conclusion on Georgia, PRESS, 27 May 2008).

32 S. Samardžić, Evropska unija..., p. 229.

33 E. Bujwid-Kurek, "EU Aspirations of the Republic of Serbia - an Overview", Przeglad Europejski, no. 2 (2016), p. 16.

34 This agreement was the subject of an assessment of the Serbian Constitutional Court, which in its conclusion of February 2nd, 2015 found its own lack of jurisdiction in this case, with the explanation that this is not a legal issue but a political act. See: B. Milosavljević (ed.), Nečasni muk Ustavnog suda povodom Kosova i Metohije, Beograd 2013, pp. 156-176. 
Agreement (municipal self-government, judiciary, police) and committed to full implementation of four previously signed agreements (mutual recognition of university diplomas, exchange of cadastral data and general register data and border crossing management). This was the biggest step towards "normalizing" the relationship between Belgrade and Priština. By fulfilling these conditions and by adopting the Brussels Agreement (January 2014), Serbia acquired the candidate status and conditions for opening the formal negotiations on its membership in the European Union. Later, Belgrade signed four more agreements with Priština: about the community of Serbian municipalities, energy, telecommunications and the passage over the Mitrovica bridge. Serbia fulfilled its obligations under these agreements, while the authorities in Priština have only fulfilled those obligations that lead to their independence, and they are still opposed to the implementation of the agreement about the community of Serbian municipalities. Each of these agreements was an addition to the renunciation of Serbia's sovereignty, property or influence in the Kosovo and Metohija territory. On the other hand, the process of accession negotiations with the European Union is still uncertain, with the EU continuing to point out that by the end of the accession negotiations, the negotiation process needs to bring about "a comprehensive normalization of relations between Serbia and Kosovo", which obviously implies the recognition of Kosovo's independence. In this same direction is a condition for a "legally binding agreement with Priština” which was presented by the German Foreign Minister Sigmar Hartmut Gabriel during his visit to Belgrade and Priština in February 2018.

One in a series of problems arising from the supplementary criteria for the Western Balkan states and the role of the European Union in disintegration processes in Yugoslavia is cooperation with the Hague Tribunal. The estimation of the level of cooperation or fulfillment of this condition was determined by the Tribunal's chief prosecutor, i.e. a body outside of the EU institutions, and his assessments were accepted by the EU without being questioned and imposed on Serbia as ultimatums. The issue of cooperation with the Hague Tribunal was constantly mentioned in all contacts between the EU representatives and Serbian officials. That is why until the extradition of Ratko Mladić (2011) it seemed that the cooperation with the Hague Tribunal was the key condition for continuation of the EU integration of Serbia. One should bear in mind that the European Union and the "international community" accused the political and military leadership of the Republic of Serbia, as well as the Serbian leaders of the post-Yugoslav entities of the last decade of the 20th century (Republika Srpska and Republika Srpska Krajina) because they opposed the breakup of Yugoslavia and the establishment of a new geopolitical map on its territory. The Serbs, therefore, entered into a direct conflict with the West, and therefore the most prominent Serbian generals and political leaders were accused of war crimes and then persecuted, arrested and delivered to the Hague Tribunal ${ }^{35}$. Many of them died in there, including the former president of Serbia, and then of FR Yugoslavia Slobodan Milosević. That is why it seems that the priority of Brussels in

35 A number of Bosnian Muslims (Bosniaks), Kosovo Albanians and Croats were also charged in the Hague Tribunal. However, the cooperation with the Hague Tribunal did not condition Croatia for its entry into the European Union. 
relations with Serbia was that the war of the 1990s would end with the Serbs accepting the defeat and their political, military and police leaders being punished. For illustration, it is enough to point out to only two examples: a Positive Feasibility Study was obtained only after the series of extraditions of military and police generals (2005) and the candidate status for EU accession was obtained several months after the extradition of General Ratko Mladić (2012). That is why the European Parliament welcomed Serbia’s cooperation with the Hague Tribunal in its resolution ${ }^{36}$.

From these atypical conditions which were continually set for Serbia, the impression is that all that the European Union has been doing in the case of Serbia since 2000 was contrary to its principles and led to even greater disintegration in the post-Yugoslav space. Therefore, the European path of Serbia seems to lead to further disintegration, destabilization, and weakening of the Serbian state, rather than its strengthening in accordance with the standard criteria applied to the countries that are now members of the European Union.

\section{POLITICAL MOOD IN SERBIA TOWARDS THE MEMBERSHIP IN THE EU}

All of the ruling elites in Serbia since 2000 have officially advocated Serbia's accession to the European Union and have worked diligently on it. The main reason why Serbia seeks to become a member of the European Union, as pointed out by Tanja Miščević, the official in the Government of the Republic of Serbia, is that after the reforms in the accession negotiations, it will become "a modern and efficient state with a better quality of life for its citizens" ${ }^{\prime 3}$. However, so far, all the results on Serbia's European path have been achieved with significant compromises and ultimatums, which was frustrating for the ruling elites, and which has fueled the anti-European mood and opposition to Serbia's accession to the European Union in the political public. That is why, in Serbia, the opinions of citizens towards its EU membership are very divided and oscillate occasionally depending on the current political events. The attitudes towards Serbia's membership in the European Union are largely created by the ruling elites, parliamentary political parties, non-governmental organizations, various interest groups, media, prominent intellectuals, artists and public figures.

From the results of the continuous public opinion polls, which have been implemented using a unique methodology since 2006 and published on the official website of the Ministry for European Integration of the Republic of Serbia, it can be noted that the attitude of citizens towards membership in the European Union is segmented into three groups: to those who support the membership, those who are opposed, as well as those who do not have a clear attitude towards it. The basic question which has been

36 European Parliament resolution of 18 April 2013..., Par. 11.

37 Informacioni centar EU u Beogradu, Pregovaračka poglavlja: 35 koraka ka Evropskoj uniji, Beograd 2015, p. 2. 
asked repeatedly since 2006 is "If there were a referendum tomorrow with a question: Do you support our country's membership in the European Union, how would you vote?" - and interesting results were obtained (See Table no. 1).

Table no. 1. Results of the public opinion polls on citizens' attitudes towards EU membership

\begin{tabular}{|c|c|c|c|}
\hline $\begin{array}{c}\text { Representation through the phases of } \\
\text { research }\end{array}$ & For (\%) & Against (\%) & $\begin{array}{c}\text { Would not vote } \\
\text { or no answer } \%\end{array}$ \\
\hline November 2006 & 70.00 & 12.00 & 18.00 \\
\hline June 2007 & 49.00 & 15.00 & 16.00 \\
\hline December 2008 & 61.00 & 13.00 & 26.00 \\
\hline May 2009 & 61.00 & 17.00 & 22.00 \\
\hline December 2009 & 65.00 & 14.00 & 21.00 \\
\hline June 2010 & 65.00 & 15.00 & 20.00 \\
\hline December 2010 & 57.00 & 18.00 & 25.00 \\
\hline June 2011 & 53.00 & 24.00 & 23.00 \\
\hline December 2011 & 51.00 & 28.00 & 21.00 \\
\hline June 2012 & 49.00 & 25.00 & 26.00 \\
\hline December 2012 & 41.00 & 31.00 & 28.00 \\
\hline July 2013 & 50.00 & 24.00 & 26.00 \\
\hline December 2013 & 51.00 & 22.00 & 27.00 \\
\hline June 2014 & 46.00 & 19.00 & 35.00 \\
\hline December 2014 & 44.00 & 25.00 & 31.00 \\
\hline June 2015 & 49.00 & 28.00 & 23.00 \\
\hline
\end{tabular}

Source: Ministry of European Integration of the Republic of Serbia ${ }^{38}$.

The basic arguments of those who support Serbia's membership in the European Union and those who oppose it can be seen in everyday political life, the media, and

38 Public opinion polls on Serbian citizens' attitudes towards Serbia's membership in the European Union were conducted for the needs of the Government of the Republic of Serbia. They have been done in precise research periods since 2006, according to a single methodology. Ministarstvo za evropske integracije Republike Srbije, Istraživanja javnog mnjenja, Beograd 2018, at <http://www.mei. gov.rs/src/dokumenta/nacionalna-dokumenta/istrazivanja-javnog-mnjenja>. 
the public opinion polls. The arguments of those who are for the European Union, are based on the estimates that the results of the European integration have provided the citizens and the EU member states with peace, security, stability, freedom of movement of people, goods and capital, balanced economic development, prosperity and high living standards. The conclusion from the above could be that Serbia's membership in the EU would be profitable, as its citizens would also enjoy these benefits. That is why it is indicated that "the effects of EU entry (are) various and, in principle, very positive" 39 . For its supporters in Serbia, especially for the Eurofanatics, the European Union "has become a symbol of good life in Serbia and an attractive goal for the people who have been in conflict with the Western world for more than two decades" ${ }^{\prime 4}$. Serbia's major EU aspirants, in addition to the current ruling parties and coalitions led by Aleksandar Vučić, the president of the Republic of Serbia, are: Democratic Party (Dragan Šutanovac), Serbian Revolutionary Movement (Vuk Drasković), Liberal Democratic Alliance (Čedomir Jovanović); as well as almost all national minority parties and many non-governmental organizations. However, the biggest advocates of Serbia's membership in the EU have evolved from the political parties and non-governmental organizations with the globalist tendencies from the $1990 \mathrm{~s}^{41}$.

The arguments of those who are against Serbia's membership in the EU are derived from the Union's relationship with Serbia during the 1990s, the NATO bombing of Serb positions in $\mathrm{BiH}$ (1995) and Serbia (1999). From this context, the policy of permanent conditionality and the extortion which is used by the Union on Serbia on various issues (cooperation with the Hague Tribunal, readmission of refugees, recognition of Kosovo, the NATO accession, change of the value system and consciousness, change of foreign policy, sanctions against Russia), both have a decisive effect on the anti-European mood in Serbia. A special aspect of the political mood in Serbia towards the EU is the attitude towards the NATO. The opposition to Serbia's membership in the NATO is very pronounced with Serbian citizens. In all its public research so far, it has never fallen below $80 \%$, and in March this year (2018) was $84 \%$, which is particularly pointed out by the pro-west agencies which conducted this type of research ${ }^{42}$. Public opinion polls have shown similar results in the recent years, especially in young people. Thus, for example, $88 \%$ of students from the University of Belgrade (April-May 2017) were against Serbia's joining the NATO ${ }^{43}$. In addition, the negative mood of Serbian citizens towards membership in the European Union also contributes to the

39 D. Lopandić, Evropska integracija..., p. 182.

40 V. Koštunica, Politička neutralnost..., p. 33.

${ }_{41}$ See more: J. Bazić, Srpsko pitanje: Političke koncepcije rešavanja srpskog nacionalnog pitanja, Beograd 2003, pp. 311-347.

42 Institut za evropske poslove, Stavovi gradana Srbije prema NATO, Beograd 2018, at <http://iea.rs/ wp-content/uploads/2018/03/Stav-gradjana-Srbije-prema-NATO-2018-1.pdf>.

43 Centar za međunarodnu javnu politiku, Rezultati istraživanja "Stavovi studenata Univerziteta u Beogradu o spoljnoj politici Srbije”, Beograd 2017, at <http://cmjp.rs/wp-content/uploads/2017/07/ Rezultati-istra\%C5\%BEivanja-Stavovi-studenata-Univerziteta-u-Beogradu-o-spoljnoj-politiciSrbije.pdf>. 
anti-European mood expressed in the EU member states and the accession candidate countries, resulting from institutional problems of the Union's functioning and issues of identity, changes in the value system and consciousness, geopolitical challenges and the consequences of the monetary and financial crisis, as well as of the increasing security risks. In this context, it is particularly pointed to: the renunciation of Iceland's candidacy, the failure of the European Constitution, Brexit, the inability to define it and disagreement over the common policy in the refugee crisis, foreign and security policy, whereby the relationship towards Russia is increasingly evident. On the other hand, many point to the fact that the EU has ceased the membership accession of the countries of the Western Balkans, including Serbia, which frees up its obligations towards them, but imposes on them the conditions and domination of them, especially making them follow its security and foreign policy. A few influential political parties in the opposition which have traditionally had a negative attitude towards the West contribute largely towards the negative mood towards Serbia's membership in the EU such as Serbian Radical Party led by Vojislav Šešelj. Then, some parties that changed their EU policy, such as the Democratic Party of Serbia led by Vojislav Kostunica, which was in power, and whose leader was the president of the FRY, and who was the one to begin the negotiations with the EU; as well as some recent, but very influential parties, such as the Serbian Movement Dveri (Boško Obradović) and the Serbian Congress - Pledgers (Srpski sabor Zavetnici, Milica Đurđević).

\section{CONCLUSIONS}

Relations between Serbia and the European Union have a long history which can be traced to right after the First World War, at the time of the emergence of the first ideas about European unity and the European community of states that would prevent a new world war. To this end, various diplomatic initiatives were taken, especially in France and Germany. These ideas and initiatives were supported by many Serbian politicians and intellectuals, who also contributed to their realization. In particular, Momcilo Ninčić, Dimitrije Mitrinović, and Dr. Živko Topalović. During the postwar reconstruction of Yugoslavia, especially after the Informbiro Resolution (1948), Socialist Yugoslavia increasingly turned towards the West and took part in European integration processes.

Yugoslavia has had well-developed relations with the Council of Europe since its inception (1949), as well as with the European Economic Community, which was particularly noticeable after 1967. Later, this cooperation was extended to the political plan. That is why at the beginning of 1990 it seemed that Yugoslavia would soon become a member of the European Community. However, due to the culmination of the crisis and the beginning of the war in Yugoslavia, all the agreements on cooperation between Yugoslavia and the European Community were soon suspended.

During the 1990s relations with the European Community and then the European Union underwent a change of course. The European Community/Union significantly 
influenced the outcomes of the Yugoslav crisis and the consolidation of new states in post-Yugoslavia territories. It immediately acknowledged and supported some, while it took up a hostile attitude towards the FR Yugoslavia (Serbia and Montenegro), joining the UN sanctions, and then imposing even heavier sanctions. These sanctions were occasionally partially lifted and then re-imposed, depending on the course of the peace process and the Serbian concessions, which lasted until the NATO bombing of Yugoslavia.

Following the overthrow of Slobodan Milosevic's regime and the power takeover of the new political elites (October 2000), the process of major changes and radical economic reforms began, as well as the process of bringing Serbia closer to the European Union, which was considered the basic precondition for stabilization and consolidation of the country. As early as October 9th, the Council of Ministers of the EU abolished most of the previous sanctions against the FR Yugoslavia. The process of renewal of political dialogue was immediately started, so Yugoslavia was included in the Stabilization and Association Process in November that year. However, this process was slow, and Serbia had consistently encountered great obstacles, unforeseen and asymmetrical conditions, political problems and conflicts. The criteria for membership of the European Union from Copenhagen and Madrid and their implementation in the case of Serbia remained in the shadow of numerous political conditions that were not set to other Balkan countries which were accession candidates. This was particularly evident in the process of separating Montenegro from the FR Yugoslavia and Kosovo and Metohija from Serbia as well as in the issues of cooperation with the Hague Tribunal.

Although FR Yugoslavia was recognized as an international legal personality the European Union did not consider FR Yugoslavia a unified political community, and as a result of that, it supported the separatist behavior of Montenegro. This was first demonstrated by the insistence that Serbia and Montenegro should separately negotiate the Stabilization and Association Agreement and then through directly supporting the separatist regime in Montenegro in the process of its separation from the state union with Serbia.

European Union had great influence even in the process of separating Kosovo and Metohija from the Republic of Serbia. Initially, the EU's policy towards Kosovo was expressed in the thesis of "first standards then status", with the aim of first reaching certain standards in a number of areas, and then approaching the consideration of status. However, the urgency of quickly resolving the status of Kosovo soon followed. Following the failure of the Ahtisaari plan and the negotiating process, the United States and the European Union began preparations for Kosovo's independence. Through its EULEX mission, the EU provided logistic support for building Kosovo's state institutions, and NATO provided the military support. Kosovo's independence was immediately recognized by the majority of EU member states as well as its institutions, and this independence was perceived as sui generis in order to provide an alibi for violating international law. The European Union continued to pressure Serbia, insisting that it should start working on "good neighbourly relations with Kosovo". The EU pressures 
and ultimatums were expressed through imposing various agreements, which were mostly accepted by Serbia. Each of them was a contribution to the renunciation of Serbia's sovereignty or influence in Kosovo and Metohija. The EU has constantly pointed out that the negotiating process should lead to "comprehensive normalization of relations between Serbia and Kosovo", which obviously implies Serbia’s recognition of Kosovo's independence.

One of the series of problems stemming from the relationship between Serbia and the EU is also cooperation with the Hague Tribunal. This issue was raised in all contacts between the representatives of the EU and the Serbian officials. That is why until the extradition of Ratko Mladić (2011) it seemed that the cooperation with the Hague Tribunal was the key condition for continuation of the EU integration of Serbia.

The attitudes of citizens of Serbia towards its EU membership are very divided and oscillate occasionally depending on the current political events. Judging by the public opinion polls, which have regularly been implemented since 2006, it can be noted that the highest number of Serbian citizens who were for EU membership was in November 2006 (70\%) and the lowest in December 2012 and June 2016 (41\%). A special aspect of the political mood in Serbia towards the EU is the attitude towards the NATO. The opposition to Serbia's membership in NATO in all the public polls so far has never fallen below $80 \%$.

The basic characteristic of contemporary relations between Serbia and the European Union is the instability of mutual trust which is determined, on the one hand, by the continuous political conditions of the EU, which in Serbia are perceived as endangering vital national and state interests; and on the other hand, the feeling of humiliation and the ineptitude of Serbian leadership, which is interpreted in the Union as a tactic and insincerity in negotiations for membership in the European Union.

\section{BIBLIOGRAPHY}

Adamović L. (ed.), Jugoslavija i Evropska ekonomska zajednica, Beograd 1988.

Bazić J., Srpsko pitanje. Političke koncepcije rešavanja srpskog nacionalnog pitanja, Beograd 2003. Bazić J., Knežević M., "Knowledge in EU Development Strategies", Knowledge. International Journal, vol. 15, no. 1 (2016).

Biserko S., Yugoslavia's Implosion. The Fatal Attraction of Serbian Nationalism, Oslo 2012.

Bujwid-Kurek E., "EU Aspirations of the Republic of Serbia - an Overview", Przeglad Europejski, no. 2 (2016).

Bujwid-Kurek E., “'Nieunijne’ państwa pojugosłowiańskie w obliczu integrującej się Europy uwag kilka”, Studia Politologiczne, vol. 47 (2018).

Bujwid-Kurek E., "Preparations of Western Balkan Countries for Integration with the European Union. Case of the Republic of Serbia", in K. Bieniek (ed.), Republika Turcji. Polityka zagraniczna i wewnętrzna, Kraków 2016.

Bujwid-Kurek E., "Republika Serbii w kontekście kryteriów kopenhaskich - studium politologiczno-prawne" Horyzonty Polityki, vol. 4, no. 8 (2013). 
Centar za međunarodnu javnu politiku, Rezultati istraživanja "Stavovi studenata Univerziteta u Beogradu o spoljnoj politici Srbije”, Beograd 2017, at <http://cmjp.rs/wp-content/ uploads/2017/07/Rezultati-istra\%C5\%BEivanja-Stavovi-studenata-Univerziteta-u-Beogradu-o-spoljnoj-politici-Srbije.pdf>, 27 March 2017.

Comprehensive Proposal for the Kosovo Status Settlement (CSP), 2 February 2007.

Council Conclusion on Georgia. PRESS, 27 May 2008.

Council Conclusions on Western Balkans. PRESS, 18 February 2008.

Council Joint Action 2008/124/CFSP of 4 February 2008 on the European Union Rule of Law Mission in Kosovo, EULEX Kosovo, Official Journal of the European Union, L 42, 16 February 2008.

Deklaracija Skupštine Jugoslavije o daljnjem uključivanju SFR Jugoslavije u integracijske procese u Evropi, Službeni list SFRJ, br. 50, Beograd, 26. januara 1990.

Deklaracija Skupštine SFRJ o evropskim integracijama, Službeni list SFRJ, br. 30, Beograd, 26. aprila 1991.

Đurković M., Iluzija Evropske unije, Beograd 2015.

European Parliament resolution of 18 April 2013 on the 2012 Progress Report on Serbia.

Grk S., "Srbija i Evropska unija - krize posle krize”, Srpska politička misao, no. 2 (2011), at <https://doi.org/10.22182/spm.3222011.6>.

Informacioni centar EU u Beogradu, Pregovaračka poglavlja: 35 koraka ka Evropskoj uniji, Beo$\operatorname{grad} 2015$.

Institut za evropske poslove, Stavovi gradana Srbije prema NATO, Beograd 2018, at <http:// iea.rs/wp-content/uploads/2018/03/Stav-gradjana-Srbije-prema-NATO-2018-1.pdf>, 25 March 2018.

Koštunica V., Politička neutralnost ili Evropska unija, Beograd 2013.

Kovačević R., Ekonomski odnosi Srbije sa inostranstvom, Beograd 2017.

Lopandić D., Evropska integracija izmedu nacije i globalizacije. EU, Balkan i Srbija, Beograd 2017. Markuš J., Bijela knjiga. Referendum u Crnoj Gori 2006. Zbornik dokumenata, Podgorica 2007. Milikić R., Zaboravljena evropska epizoda. Jugoslavija i Savet Evrope, 1949-1958, Beograd 2014. Milosavljević B. (ed.), Nečasni muk Ustavnog suda povodom Kosova i Metohije, Beograd 2013.

Ministarstvo za evropske integracije Republike Srbije, Istorijat odnosa Srbije i EU, Beograd 2018, at <http://www.mei.gov.rs/src/srbija-i-eu/istorijat-odnosa-srbije-i-eu/>, 26 February 2018 .

Ministarstvo za evropske integracije Republike Srbije, Istraživanja javnog mnjenja, Beograd 2018, at <http://www.mei.gov.rs/src/dokumenta/nacionalna-dokumenta/istrazivanja-javnogmnjenja>, 10 February 2018.

Ministarstvo za evropske integracije Republike Srbije, Sporazumi sa EU, Beograd 2018, at <http://www.mei.gov.rs/src/dokumenta/sporazumi-sa-eu/>, 27 March 2018.

Nikolić G., Pokazatelji spoljnotrgovinske razmene Srbije sa Evropskom unijom i svetom, Beograd 2010.

Petković R., Savet Evrope 1949-1996, Beograd 1996.

Rosamond B., Theories of European Integration, New York 2000.

Samardžić S., Evropska unija. Sistem u krizi. Sa studijom slučaja o odnosima Srbije i EU, Novi Sad 2016. 
Sporazum o stabilizaciji i pridruživanju između Evropskih zajednica i njihovih država članica, sa jedne strane, i Republike Srbije, sa druge strane, koji je potpisan 29. aprila 2008. godine u Luksemburgu, Službeni glasnik Republike Srbije, br. 83, septembar 2008.

Stojković M., Balkanski ugovorni odnosi 1876-1996. Dvostrani i višestrani medunarodni ugovori i drugi diplomatski akti o državnim granicama, političkoj i vojnoj saradnji, verskim i etničkim manjinama, vol. 3: 1946-1996, Beograd 1999.

Ustavna povelja Državne zajednice Srbija i Crna Gora, Službeni list Srbije i Crne Gore, br. 1, Beograd, 4. februar 2003.

Živković A., "Kratka historija evropskih integracija”, in M. Kostanić (ed.), Dva desetljeća poslije kraja socijalizma. Zbornik radova, Zagreb 2014.

Jovan BAZIĆ - a full professor at the University of Priština-Kosovska Mitrovica, which is part of the educational system of the Republic of Serbia. He studied at the Faculty of Political Science of the University of Belgrade and received his doctorate at the same faculty, at the Department of Political Theory, Sociology and Methodology. At the same time, he is also a longtime researcher at the Institute of Political Studies in Belgrade. He has published two monographs: Srpsko pitanje: Političke koncepcije rěsavanja srpskog pitanja (2003) (The Serbian Question: Political Concepts of Solving Serbian Issues) and Drustveni aspekti obrazovanja (2012) (Social Aspects of Education); university textbook Sociologija (Sociology) (2004) in co-authorship with Mihailo Pešić, which had 12 different editions; as well as hundreds of papers in scientific journals. His areas of interest are social relations in education, social change and processes in Europe, social identities and interethnic relations in post-Yugoslavia territories. 